\title{
Pterodon pubescens Benth: Stability Study of Microencapsulated Extract and Isolated Compounds Monitored by Antinociceptive Assays
}

\author{
Leila Servat, ${ }^{a, b}$ Humberto M. Spindola, ${ }^{a, b}$ Rodney A. F. Rodrigues, ${ }^{a}$ Ilza M. O. Sousa, ${ }^{a}$ \\ Ana L. T. G. Ruiz, ${ }^{a}$ João E. de Carvalho ${ }^{a, b}$ and Mary A. Foglio*,a,b \\ ${ }^{a}$ Centro Pluridisciplinar de Pesquisas Químicas, Biológicas e Agrícolas (CPQBA), \\ Universidade Estadual de Campinas, CP 6171, 13083-970 Campinas-SP, Brazil \\ ${ }^{b}$ Área de Farmacologia, Anestesiologia e Terapêutica, Departamento de Ciências Fisiológicas, \\ Faculdade de Odontologia de Piracicaba, Universidade Estadual de Campinas, \\ CP 52, 13414-903 Piracicaba-SP, Brazil
}

\begin{abstract}
As sementes de Pterodon pubescens Benth. (Pp), disponíveis comercialmente no Brasil, são utilizadas na medicina popular em preparações anti-inflamatórias, analgésicas e anti-reumáticas. $\mathrm{O}$ presente estudo demonstrou as propriedades antinociceptivas da mistura de isômeros $6 \alpha$-hidroxi-7 $\beta$ acetoxi-vouacapano-17 $\beta$-oato de metila e $6 \alpha$-acetoxi-7 $\beta$-hidroxi-vouacapano-17 $\beta$-oato de metila (C1) isolada de Pp, empregando modelos experimentais diferentes. Um estudo de estabilidade foi realizado para investigar a relação da microencapsulação por "spray-drying" na manutenção do efeito antinociceptivo. Para isso, amostras de $\mathrm{C} 1$ e extrato de Pp foram monitorados no estudo de estabilidade acelerada, avaliando tanto amostras microencapsuladas como não microencapsuladas. Foi observado que a amostra $\mathrm{C} 1$ possui atividade antinociceptiva, revelada pelos ensaios das contorções abdominais e de formalina; foi observada também atividade significativa antialodínica, mas não efeito anti-hiperalgésico. A microencapsulação manteve a atividade e integridade de $\mathrm{C} 1$ e do extrato bruto de $\mathrm{Pp}$, demonstrando que a microencapsulação por "spray drying" é uma alternativa útil para aumentar o tempo de prateleira.
\end{abstract}

Pterodon pubescens Benth. (Pp) seeds, commercially available in Brazil, are used in folk medicine in anti-inflammatory, analgesic, and anti-rheumatic preparations. The present study demonstrated the antinociceptive properties of isomers $6 \alpha$-hydroxy- $7 \beta$-acetoxy-vouacapan- $17 \beta$ oate methyl ester and $6 \alpha$-acetoxy-7 $\beta$-hydroxy-vouacapan-17 $\beta$-oate methyl ester $(\mathrm{C} 1)$, isolated from (Pp), employing different experimental models. A stability study was performed to investigate the relationship of microencapsulation by spray-drying on the maintenance of antinociceptive action. Therefore, $\mathrm{C} 1$ and $\mathrm{Pp}$ extract samples were monitored in accelerated stability study, evaluating both microencapsulated and non-microencapsulated samples. It was observed that sample $\mathrm{C} 1$ possess antinociceptive activity revealed by writhing and formalin tests; $\mathrm{C} 1$ showed significantly anti-allodynic, but not antihyperalgesic effect; the microencapsulation maintained the activity and integrity of both, sample $\mathrm{C} 1$ and Pp crude extract; microencapsulation by spray drying is a useful alternative to increase shelf life.

Keywords: microcapsules, stability, spray-drying, antinociceptive, Pterodon pubescens

\section{Introduction}

Pterodon pubescens Benth. (Leguminosae) seeds are commercially available in Brazil. The plant's crude alcoholic extract is used in folk medicine in antiinflammatory, analgesic, and anti-rheumatic preparations. ${ }^{1,2}$ Phytochemical studies of Pterodon genus have revealed the

*e-mail: foglioma@cpqba.unicamp.br presence of alkaloids, isoflavones and diterpenes. Furan diterpenes were identified and isolated from Pterodon species. ${ }^{3-7}$ Authors have reported that furanoditerpenes possessing vouacapan skeleton are involved with the anti-inflammatory, antinociceptive and antiproliferative properties of Pterodon pubescens seed crude extract. ${ }^{7-12}$

We previously reported the antinociceptive properties of geranylgeraniol and $6 \alpha, 7 \beta$-dihydroxy-vouacapan-17 $\beta$-oate methyl ester, compounds isolated from Pterodon pubescens 
Benth seeds. ${ }^{12}$ This report gives sequence to that study, evaluating the antinociceptive properties of isomers $6 \alpha$-hydroxy- $7 \beta$-acetoxy-vouacapan-17 $\beta$-oate methyl ester

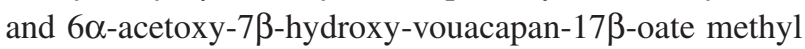
ester (C1) isolated from P. pubescens crude extract, as well as the influence of the microencapsulation process as a tool for maintaining stability of both the crystals and extracts. Therefore, we evaluated microencapsualed and free samples of $\mathrm{C} 1$ and the crude extract on the antinociceptive assays.

\section{Experimental}

\section{General experimental procedures}

IR spectra were recorded on a JASCO-FT/IR-410 spectrometer. ${ }^{1} \mathrm{H},{ }^{13} \mathrm{C}$ NMR and $2 \mathrm{D}$ experiments were conducted on a Varian Inova-500 spectrometer (11 T). Chemical shifts were recorded in $\mathrm{CDCl}_{3}$ solutions and quoted relative to TMS $\left(\delta_{\mathrm{H}} 0.0,{ }^{1} \mathrm{H} \mathrm{NMR}\right)$ and $\mathrm{CHCl}_{3}$ $\left(\delta_{\mathrm{H}} 77.0,{ }^{13} \mathrm{C} \mathrm{NMR}\right)$. High-resolution electron inpact ionization mass spectrometry (HREIMS) was recorded on a VG-AutoSpec high resolution mass spectrometer $(70 \mathrm{eV})$ using direct probe. GC/MS was carried out using a HP-6890/5970 system equipped with a J\&W Scientific DB-5 fused capillary column $(25 \mathrm{~m} \times 0.2 \mathrm{~mm} \times 0.33 \mu)$. Temperature program was $40\left(5^{\circ} \mathrm{C} \mathrm{min}^{-1}\right)-300^{\circ} \mathrm{C}(10 \mathrm{~min})$. Injector $250^{\circ} \mathrm{C}$, detector $300^{\circ} \mathrm{C}$. Helium was used as carrier gas $\left(0.7 \mathrm{bar}, 1 \mathrm{~mL} \mathrm{~min}^{-1}\right)$. The MS were taken at $70 \mathrm{eV}$. Scanning speed was 0.84 scans s$^{-1}$ from 40 to 550 . Sample volume was $1 \mu \mathrm{L}$. Split: 1:40. Column chromatography (CC): silica gel $\left(0.063 \times 0.200 \mathrm{~mm}\right.$, Merck $\left.^{\circledR}\right)$. TLC (thin layer chromatography): precoated plates $\left(775554 \mathrm{Merck}^{\circledR}\right)$, UV detection and anisaldehyde solution.

\section{Phytochemistry}

\section{Plant material}

Pterodon pubescens $(\mathrm{Pp})$ seeds were previously collected in Minas Gerais state (Ponto Chique city), in March 2008 and identified by Prof. Dr. Jorge Yoshio Tamashiro from IB-Unicamp (Department of Botany), who identified the plant species. A voucher specimen was deposited at the University of Campinas (Unicamp) Herbarium, under number 1402.

\section{Extracts production and compounds isolation}

Freeze-dried seeds ( $1000 \mathrm{~g}$ ) were ground in mill (POLI model LS-06) and extracted with dichloromethane three times during $2 \mathrm{~h}$ periods, with 5:1 solvent/plant ratio, at room temperature. The extract was dried over anhydrous $\mathrm{Na}_{2} \mathrm{SO}_{4}$ to remove residual water, filtered and concentrated under vacuum (BUCHI model RE 215), providing the crude extract in $40 \%$ yield.

The crude extract ( $240 \mathrm{~g}$ ) was chromatographed over silica gel (1900 g) and eluted sequentially with n-hexane/ ethyl acetate gradients. The fractions were monitored by thin layer chromatography (TLC). The TLC plates were sprayed with $p$-anisaldehyde reagent $(50 \mathrm{~mL}$ acetic acid, $0.5 \mathrm{~mL}$ sulfuric acid and $0.5 \mathrm{~mL} p$-anisaldehyde) followed by heating at $100{ }^{\circ} \mathrm{C}$. Similar fractions were grouped according to their TLC profile. The fractions that were eluted with hexane:ethyl acetate (75:25) providing fraction $\mathrm{E}$, gave crystals $(8.4 \mathrm{~g} ; 3.5 \%)$. The crystals were analysed by gas chromatography (GC-MS) with identification of an isomers mixture. Comparison of the physical and spectral data (mass, ${ }^{1} \mathrm{H}$ NMR, ${ }^{13} \mathrm{C}$ NMR) of sample $\mathrm{C} 1$ with reported data ${ }^{4-6}$ provided identification of the isomer mixture as a 1:1 ratio of (i) $6 \alpha$-hydroxy- $7 \beta$-acetoxy-vouacapan-17 $\beta$-oate methyl ester and (ii) $6 \alpha$-acetoxy-7 $\beta$-hydroxy-vouacapan$17 \beta$-oate methyl ester. The isomers mixture showed a melting point in the range of $178-182^{\circ} \mathrm{C}$.

\section{Microcapsules production}

\section{Pp extract and $\mathrm{C} 1$ microencapsulation}

A mini spray-dryer Buchi, model B-290, with inert loop B-295 (Flawil, Switzerland) was used for the microencapsulation process; operating conditions are shown in Table 1.

Table 1. Operating conditions of the spray-dryer in the microencapsulation process, using maltodextrin and arabic gum as wall material

\begin{tabular}{lc}
\hline Operating conditions & \\
\hline Core conc. (crude extract or vouacapan in relation of total & 20 \\
solids) / \% & \\
Wall conc. (maltodextrin/arabic gum 1:1 in relation of total & 80 \\
solids) / \% & 30 \\
Total solids conc. in relation of final volume / \% & 10 \\
Liquid flow rate: spray / $\left(\mathrm{mL} \mathrm{min}^{-1}\right.$ ) & $180 \pm 5$ \\
Entrance air temperature: $\mathrm{spray} /{ }^{\circ} \mathrm{C}$ & $100 \pm 10$ \\
\hline Exit air temperature: $\mathrm{spray} /{ }^{\circ} \mathrm{C}$ &
\end{tabular}

Samples were homogenized with maltodextrin/arabic gum (1:1) in a ratio of $2: 8$, using Tween $80^{\circledR}$ as emulsifier and IKA $^{\circledR}$ T10Basic-Ultra Turrax $^{\circledR}$.

\section{Particle morphology}

The samples processed by spray-dryer were set at a double-sided adhesive tape in cylindrical aluminum (stubs) according to the procedure described by Rosemberg and Young. ${ }^{13}$ The cylinders were subjected to metallization by coating with a thin layer of gold using a current of $40 \mathrm{~mA}$ 
during $180 \mathrm{~s}$ under vacuum. This technique, known as sputtering, was performed in an evaporator (Balzer). The morphology of the samples was evaluated using a scanning electronic microscope (JEOL), operating at $10 \mathrm{kV}$.

\section{Stability evaluation}

Microcapsules produced were stored at climate chamber, with constant temperature $\left(40{ }^{\circ} \mathrm{C}\right)$ and humidity (70\%). Samples of microencapsulated $\mathrm{C} 1$ were taken at $0,30,60,150$ and 180 days and of microencapsulated Pp extract, were taken at 0 and 180 days. The samples were submitted to antinociceptive activity assay. Pp extract and $\mathrm{C} 1$ without encapsulation were used as a control.

\section{Pharmacology}

\section{Drugs}

All drugs and compounds were diluted with Tween ${ }^{80}$ $1 \%$ (Sigma-Aldrich, USA) in $0.9 \%$ saline solution $(\mathrm{NaCl}$ diluted in distilled water), $\mathrm{C} 1$ microencapsulated was diluted with saline solution. The following substances were used: pentobarbital, indomethacin, morphine hydrochloride (Cristália, Brazil), acetic acid, complete Freund's adjuvant (CFA), carrageenan (Sigma- Aldrich, USA) and formaldehyde (Chemco-Brasil).

\section{Animals}

Male Swiss mice (25-35 g) and Wistar rats (150-250 g) were kept at $25 \pm 2{ }^{\circ} \mathrm{C}$ exposed to $12 \mathrm{~h}$ light-dark cycles (the light phase starting at 7:00 am) and maintained in animal facilities (10 and 5 animals per cage, respectively) with water and food ad libitum, for at least 7 days prior to the assays. Separate groups of mice and rats were used only once for each experiment, except in the hyperalgesia and allodynia assays. The intraperitoneal (i.p.) route was used for all experiments, based on previous report. ${ }^{12}$ Studies were carried out in accordance with the current guidelines for veterinary care of laboratory animals ${ }^{14}$ and were performed under the consent and surveillance of Unicamp's Institute of Biology Ethics Committee for Animal Research (1951-1).

\section{Evaluation of locomotor activity}

The ambulatory behavior was assessed in an open-field test as described previously. ${ }^{12}$ The apparatus consisted of a plastic box measuring $45 \times 45 \times 20 \mathrm{~cm}$, with the floor divided into 9 equal squares $(15 \times 15 \mathrm{~cm})$. The number of squares crossed with all paws (crossing) was counted in a 3-min session. Mice were $30 \mathrm{~min}$ previously treated intraperitoneally (i.p.) with $\mathrm{C} 1\left(30 \mathrm{mg} \mathrm{kg}^{-1}\right)$, pentobarbital (35 $\mathrm{mg} \mathrm{kg}^{-1}$ ) or vehicle. Results were expressed as mean \pm S.E.M. of 4 animals per group.
Abdominal constriction induced by acetic acid (writhing test)

The writhing test was carried out as described previously. ${ }^{12}$ Groups of mice $(n=6)$ were treated i.p. with vehicle $\left(10 \mathrm{~mL} \mathrm{~kg}^{-1}\right)$, indomethacin $\left(30 \mathrm{mg} \mathrm{kg}^{-1}\right)$ or sample $\mathrm{C} 1$, in a dose-dependent manner: $10,30,100$, and $300 \mathrm{mg} \mathrm{kg}^{-1}$, to determine the effective dose $\left(\mathrm{ED}_{50}\right)$. Writhing was induced by an i.p. injection of $0.8 \%$ acetic acid solution $\left(0.1 \mathrm{~mL}\right.$ per $\left.10 \mathrm{~kg}^{-1}\right), 30 \mathrm{~min}$ after treatment. After injection of the acetic acid solution, the numbers of writhings (abdominal constrictions) were cumulatively counted over $15 \mathrm{~min}$, for nociception measurement. Data represents the average of the total writhing observed per dose concentration.

\section{Formalin test}

The procedure was the same as described by Hunskaar and Hole, ${ }^{15}$ with few changes. The nociceptive stimulus is a subplantar (s.pl.) injection of formalin solution (2\% formaldehyde in PBS; $20 \mu \mathrm{L}$ per paw) into the dorsal surface of the right hind paw of the mice. Groups of animals $(n=6)$ were treated with sample $\mathrm{C} 1(3,10,30$ and $100 \mathrm{mg} \mathrm{kg}^{-1}$, i.p.) $30 \mathrm{~min}$ before the formalin injection. Indomethacin (30 $\mathrm{mg} \mathrm{kg}^{-1}$, i.p.) and morphine $\left(10 \mathrm{mg} \mathrm{kg}^{-1}\right.$, i.p.) were used as reference drugs. Control animals received only the vehicle. The animals were placed individually in an observation chamber made of transparent acrylic to allow clear observation of the animal's paws. The amount of time the animal spent licking the injected paw, indicative of pain, was recorded during $45 \mathrm{~min}$ after formalin injection. The initial nociceptive scores peaked $5 \mathrm{~min}$ after formalin injection (early phase) and 25-45 min after formalin injection (late phase), representing the neurogenic and inflammatory pain responses, respectively.

\section{Mechanical allodynia induced by complete Freund adjuvant} (CFA)

The procedures were developed and standardized in our laboratory based on the method previously described ${ }^{16}$ with changes in protocol and data analysis. Different groups of rats $(n=5)$ were used, and inflammation was induced with a solution of CFA $\left(1 \mathrm{mg} \mathrm{mL}^{-1}\right.$ of heat killed Mycobacterium tuberculosis in $85 \%$ paraffin oil and $15 \%$ mannide monoleate) injected $(0.1 \mathrm{~mL})$ into the plantar surface of the right hind paw. The left hind paw received the same volume of saline solution $(\mathrm{NaCl} 0.9 \%$ diluted in distilled water) in order to equalize the sensibility of animals caused by the injection. Mechanical allodynia was assessed using the dynamic plantar anaestesiomether apparatus (Ugo Basile, model 37450, Italy), which consisted of an elevated wire mesh platform to allow access to the ventral surface of the hind paws. A steel rod (diameter 
$0.5 \mathrm{~mm}$ ) was pushed against the hind paw with ascending force (touch stimulator). The force ranged from 0 to $35 \mathrm{~g}$ over a $20 \mathrm{~s}$ period. When the animal withdrew the hind paw, the mechanical stimulus was automatically stopped, and the force applied by the animal to withdraw the paw was recorded to the nearest $0.1 \mathrm{~g}$. An allodynia score was determined after four consecutive measurements using the touch stimulator sequentially on the left and right hind paw and calculated considering the formula below determined by the authors:

\section{Left hind paw value $/$ Right hind paw value $=$ Allodynia score}

The basal score was measured before CFA injection on day 0 , and animals considered for testing were those with a mean value nearest to 1 (demonstrating no significant difference between both paw stimuli). After CFA injection, measurements were carried out considering three different phases, as follows: $4 \mathrm{~h}$ on day 0 (acute pain); $24 \mathrm{~h}$ on day 1 (sub-acute pain) and on day 14 (chronic pain). Vehicle $\left(10 \mathrm{~mL} \mathrm{~kg}^{-1}\right)$ or sample $\mathrm{C} 1$ were administered $\left(30 \mathrm{mg} \mathrm{kg}^{-1}\right.$, i.p.) $30 \mathrm{~min}$ prior to touch stimulation, in order to evaluate the possible anti-allodynic activity observed for each phase. A positive control was not employed as the aim of this test was to evaluate the activity of compounds using doses equal to those used in the tests described below for evaluating potential antinociceptive mechanisms.

\section{Mechanical hyperalgesia induced by carrageenan}

The procedures used for this study were similar to those described previously ${ }^{17}$ with some changes in the protocol and data analysis. Different groups of rats $(n=6)$ were submitted to pressure stimulus ( 0 to $500 \mathrm{~g}$ ) on the right hind paw using an analgesy-meter (Ugo Basile, model $37215 / 372116$, Italy) prior to carrageenan injection, in order to determine the basal value. The hypernociceptive response was considered when animals vocalized or withdrew the paw from the equipment, demonstrating pain. After this first measurement, animals received a carrageenan $(0.1 \mathrm{~mL})$ intraplantar (i.pl.) injection (2.5\% in saline) into the right hind paw surface. After $2.5 \mathrm{~h}$, they were submitted to pressure again, to evaluate whether the hypernociceptive state was reached ( $40 \%$ decrease). Animals were than treated with vehicle $\left(10 \mathrm{~mL} \mathrm{~kg}^{-1}\right.$, i.p. - negative control), indomethacin ( $30 \mathrm{mg} \mathrm{kg}^{-1}$, i.p. - positive control) and sample C1 (30 $\mathrm{mg} \mathrm{kg}^{-1}$, i.p.), and the mechanical hyperalgesia was evaluated after $30 \mathrm{~min}, 1 \mathrm{~h}, 2 \mathrm{~h}$ and $3 \mathrm{~h}$. The value demonstrating mechanical hyperalgesia was obtained after each measurement, and the results were shown as decreased percentage compared to the pressure tolerated in the basal $(100 \%)$ value for each group.

\section{Statistical analysis}

All results were submitted to one way analysis of variance (ANOVA) with repeated measurements, $\mathrm{p} \leq 0.05$ was considered the critical level for evaluating significant difference between the control and treated groups, followed by Duncan's Test, using StatSoft ${ }^{\circledast}$ software. Graphs were designed using the Origin ${ }^{\circledR}$ software.

\section{Results and Discussion}

In the present study, we investigated the antinociceptive activity of vouacapans sample C1 (Figure 1) isolated from P. pubescens $(\mathrm{Pp})$, employing different experimental models. A stability study was performed to investigate the influence of microencapsulation by spray-drying on maintenance of antinociceptive action. For this purpose, were monitored sample $\mathrm{C} 1$ and $\mathrm{Pp}$ crude extract activity in acelerated stability study (180 days period), comparing both microencapsulated and non-microencapsulated samples.

The most relevant findings of this paper were that sample C1 (i) possess antinociceptive activity revealed by writhing test; (ii) is more effective on the first phase (neurogenic pain) then second phase (inflammatory pain) of formalin test; (iii) showed significantly anti-allodynic, but not antihyperalgesic effect; (iv) the microencapsulation kept the activity and integrity of both, sample $\mathrm{C} 1$ and $\mathrm{Pp}$ crude extract; $(v)$ microencapsulation by spray drying is a useful alternative to increase shelf life time.
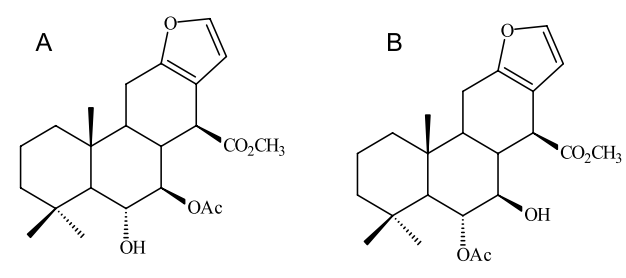

$C 1(A+B)$

Figure 1. Isomers molecular structures that constitute the mixture denominated sample C1; A) $6 \alpha$-hidroxy-7 $\beta$-acetoxy-vouacapan-17 $\beta$ oate methyl ester and B) $6 \alpha$-acetoxy-7 $\beta$-hidroxy-vouacapan-17 $\beta$-oate methyl ester.

Evaluation of $\mathrm{C} 1$ antinociceptive, anti-hypernociceptive and anti-allodynic activities

Initially, the open field test was performed in order to exclude the possibility of the sample $\mathrm{C} 1$ action could be related to non-specific disturbances in the locomotor activity of the animals. ${ }^{12}$ The treatment with sample $\mathrm{C} 1$ (30 mg kg-1 i.p.) did not cause any significant change 
in the ambulation of mice when tested in the open field. However, pentobarbital (35 $\mathrm{mg} \mathrm{kg}^{-1}$, i.p.) significantly $(\mathrm{p}<0.001)$ reduced the locomotor activity of animals in this test. The mean number of crossings was $48.2 \pm 2.2$, $13.7 \pm 6.1,40 \pm 9$ for vehicle, pentobarbital and sample $\mathrm{C} 1$, respectively.

With this result, the antinociceptive properties of sample $\mathrm{C} 1$ were evaluated using the writhing test. Aceticacid induced pain is a screening tool for the assessment of analgesic or anti-inflammatory properties of natural or synthetic compounds. Inflammatory pain transmission primarily involves peripheral polymodal receptors around small vessels which signal to the CNS via sensory afferent $\mathrm{C}$-fibers entering the dorsal horn. Acetic acid may act indirectly by inducing the release of endogenous mediators, which stimulate the nociceptive neurons and can be blocked by nonsteroidal anti-inflammatory drugs (NSAIDs) and opioids. ${ }^{18}$ This method has good sensitivity but poor specificity allowing misinterpretation of the results. This problem can be avoided by complementation with other nociception models, as described here.

The results presented in Figure 2 showed that sample $\mathrm{C} 1$ produced a significant effect, reducing writhings of the mice in a dose-dependent manner, compared to the control group (vehicle only), presenting $\mathrm{ED}_{50}=35.6 \mathrm{mg} \mathrm{kg}^{-1}$.

In order to confirm this property, and distinguish this action between inflammatory and neurogenic pain, the formalin test was performed. The intraplantar injection of formalin produces a biphasic response characterized by an immediate and intense increase in the spontaneous activity followed by a quiescent phase and then a more prolonged increase in cell firing of both primary afferents as well as dorsal horn neurons. ${ }^{19}$ Neurogenic pain is

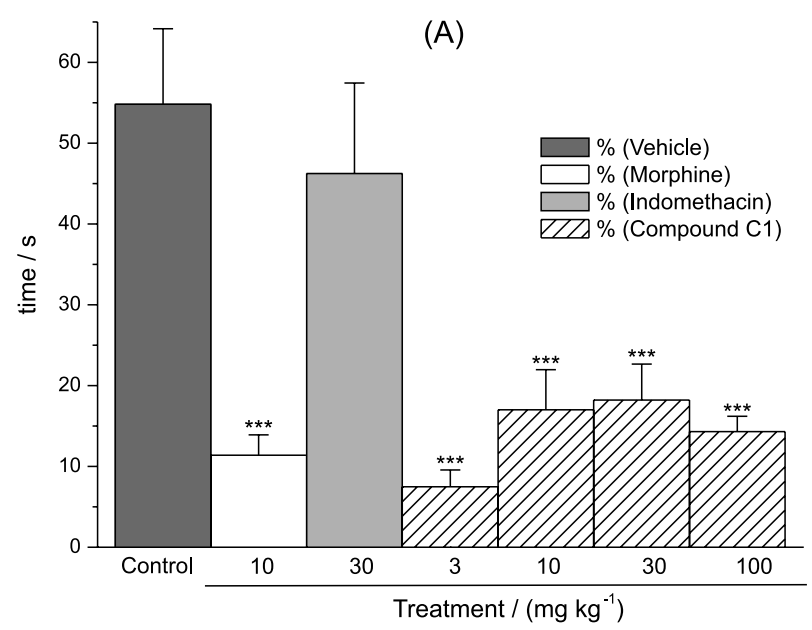

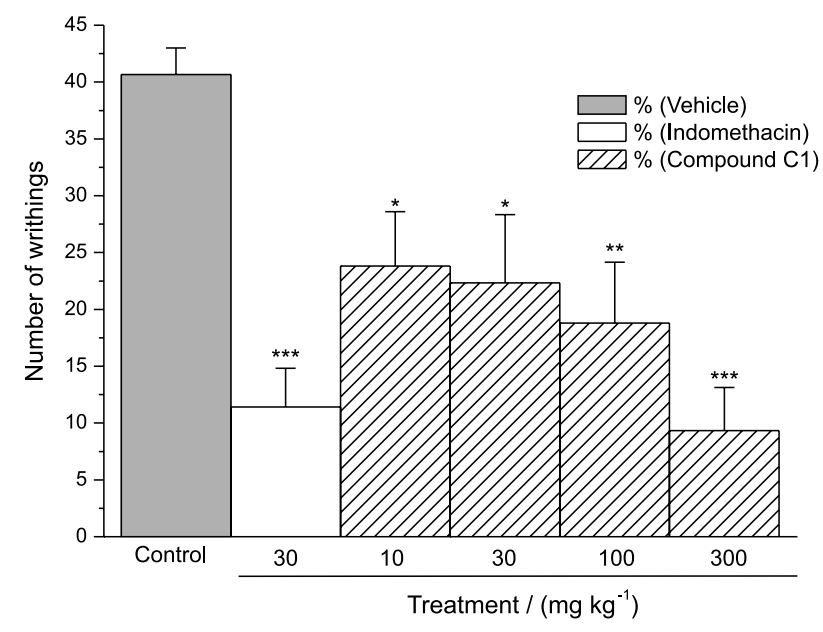

Figure 2. Graph demonstrating effects of sample $\mathrm{C} 1$ against the acetic acidinduced writhing in mice. Animals were pretreated $(30 \mathrm{~min})$ with vehicle $\left(10 \mathrm{~mL} \mathrm{~kg}^{-1}\right), \mathrm{C} 1$ (doses 10, 30, 100 and $300 \mathrm{mg} \mathrm{kg}^{-1}$; i.p.) or indomethacin (30 $\mathrm{mg} \mathrm{kg}^{-1}$; i.p.). Each column represents the mean \pm S.E.M. for six mice in each group. (*p $\leq 0.05, * * \mathrm{p} \leq 0.01, * * * \mathrm{p} \leq 0.001)$.

caused by direct activation of nociceptive nerve terminals, while inflammatory pain is mediated by a combination of peripheral input and spinal cord sensitization. ${ }^{15}$ Intraplantar injection of formalin in rodents produces significant increases in spinal levels of different mediators, such as excitatory amino acids, $\mathrm{PGE}_{2}$, and nitric oxide, as well as kinins and other peptides. ${ }^{20}$ Furthermore, systemic spinal and supraspinal administration of tachykinin receptor antagonists, NOS inhibitors, NMDA receptor antagonists, opioids, $\alpha_{2}$-adrenoceptor agonist, and NSAIDs can all antagonize formalin induced nociception..$^{21}$

As shown in Figure 3, treatment with sample C1 produced a marked reduction of the licking time in the first phase. This result suggests that the antinociceptive action

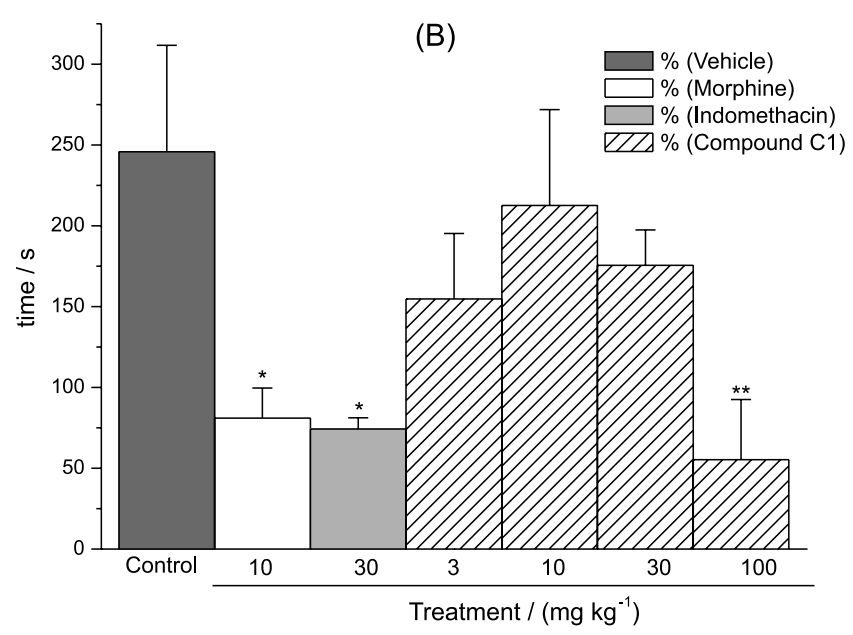

Figure 3. Graph demonstrating effects of sample C1on the licking induced by formalin in mice. Animals were pretreated with vehicle, $\mathrm{C} 1$ (doses 3 , 10, 30 and $300 \mathrm{mg} \mathrm{kg}^{-1}$; i.p.), indomethacin $\left(30 \mathrm{mg} \mathrm{kg}^{-1}\right.$; i.p.) or morphine $\left(10 \mathrm{mg} \mathrm{kg}^{-1}\right.$; i.p.) prior to formalin. The total time spent licking the hindpaw was measured in the first (A) and second (B) phases after intraplantar injection of formalin. Each column represents the mean \pm S.E.M. for six mice in each group. $* \mathrm{p} \leq 0.05, * * \mathrm{p} \leq 0.01, * * * \mathrm{p} \leq 0.001)$ 
may be related to both central and peripheral mechanisms. In the second phase (inflammatory pain), sample $\mathrm{C} 1$ was effective only at the highest doses $\left(100 \mathrm{mg} \mathrm{kg}^{-1}\right)$. The reference drug indomethacin $\left(30 \mathrm{mg} \mathrm{kg}^{-1}\right)$ inhibited pain induced by formalin in the second phase, whereas morphine $\left(10 \mathrm{mg} \mathrm{kg}^{-1}\right)$ significantly attenuated the pain responses of both phases.

Next, we investigated the anti-hypernociceptive effect of sample $\mathrm{C} 1$ induced by carrageenan in rats. Carrageenaninduced hind paw inflammation is a neutrophil-mediated acute inflammatory response that produces hind paw swelling, erythematic and localized hyperthermia.22 This inflammatory method has become a widely used model for studying acute inflammation, involving macrophages, mast cells, and endothelial cells. ${ }^{23}$ The results presented in Figure 4 showed that indomethacin $\left(30 \mathrm{mg} \mathrm{kg}^{-1}\right.$, i.p.) produced significant anti-hypernociception activity increasing the percentage of stimulus compared to the control group (vehicle), whereas sample $\mathrm{C} 1\left(30 \mathrm{mg} \mathrm{kg}^{-1}\right.$, i.p.) did not present any effect $30 \mathrm{~min}, 1 \mathrm{~h}, 2 \mathrm{~h}$ and $3 \mathrm{~h}$ after carrageenan injection. In this assay, which has essentially inflammatory components, sample $\mathrm{C} 1$ was not effective, suggesting that $\mathrm{C} 1$ has a higher affinity for neurogenic components, corroborating the results observed in the second phase of the formalin test, in which there was a need to increase dosage to have activity in inflammatory pain.

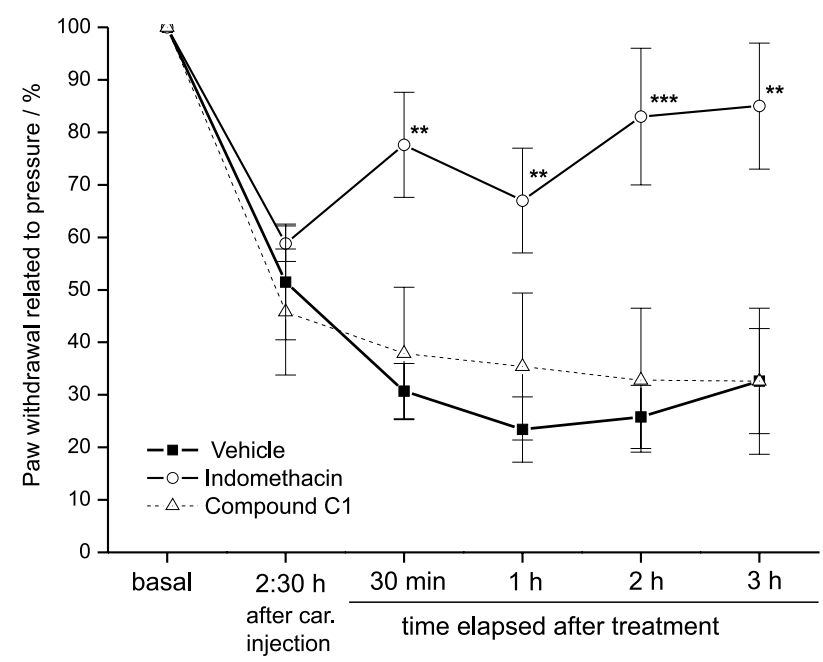

Figure 4. Graph demonstrating results of vocalization or paw with drawal related to pressure exerted in the right hind paw in response to the hypernociception caused by injection of carrageenan $(2.5 \%, 0.1 \mathrm{~mL})$ in rats treated with indomethacin or sample $\mathrm{C} 1\left(30 \mathrm{mg} \mathrm{kg}^{-1}\right.$, i.p.) compared to the control group (vehicle). Results expressed as reduction percentage means \pm S.E.M. of 5 animals for experimental groups compared to the basal values (considered 100\%) (**p $\leq 0.01 ; * * * \mathrm{p} \leq 0.001)$.

Finally, the anti-allodynic effect of sample $\mathrm{C} 1$ was evaluated throughout a persistent pain model caused by complete Freund adjuvant (CFA). Allodynia (pain-like responses to normally innocuous stimuli) was induced by CFA intraplantar injection, ${ }^{24}$ which involves central sensitization due to the release of multiple inflammatory and pain mediators that account for sensitivity increase of both peripheral sensory afferents at the injury site, and in the central nervous system. ${ }^{25}$

The results presented in Figure 5 showed that sample C1 $\left(30 \mathrm{mg} \mathrm{kg}^{-1}\right.$, i.p.) produced a significant anti-allodynic effect reducing the allodynic score compared to the control group during the acute $(4 \mathrm{~h}$ post $\mathrm{CFA})$ and sub acute phases ( $24 \mathrm{~h}$ post CFA) of the test. Sample $\mathrm{C} 1$ exerted no activity during the chronic phase (14 days post CFA). These results demonstrated the activity of sample $\mathrm{C} 1$ during the acute and sub acute phases of allodynic response, suggesting activity related to central and/or peripheral pathway.

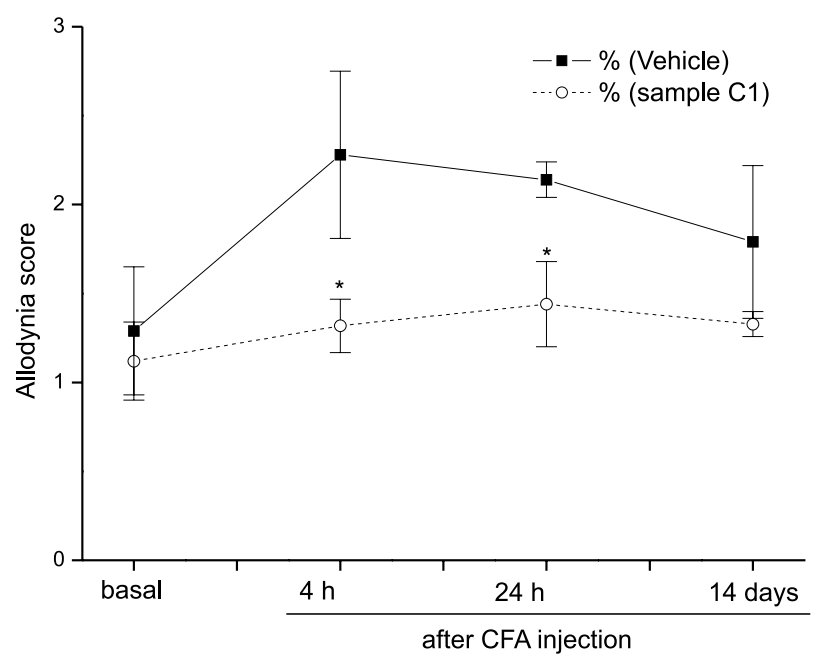

Figure 5. Graph demonstrating decrease on allodynia score related to the touch stimulation exerted on the surface of the left and right hind paws caused by injection of saline solution and CFA $(0.1 \mathrm{~mL})$ respectively, producing persistent pain sensitization in rats treated with sample $\mathrm{C} 1$ (30 $\mathrm{mg} \mathrm{kg}^{-1}$, i.p.) compared to the control group (vehicle, $10 \mathrm{~mL} \mathrm{~kg}^{-1}$ ). Results expressed as reduction score means \pm S.E.M. of 5 animals for experimental groups $(* \mathrm{p} \leq 0.05)$.

\section{Evaluation stability study}

Spray-drying is the most commonly used method in the herbal processing industries, but there are few reports on the influence of adjuvants and technological processing on the herbal extracts or herbal substances. ${ }^{26}$ In the development of herbal medicines, bioguided techniques have been the methods of choice among the technological processes. This approach allows optimizing formulations with a view toward maximizing the therapeutic effect. ${ }^{27}$ This study evaluated for the first time the contribution of microencapsulation by spray drying in stability of crude extract and isolated compounds, employing antinociceptive activity assays. 
Once we demonstrated the potential use of $\mathrm{C} 1$ for pain relief, we proceed to evaluate the microencapsulation by spray-drying processes as a tool for maintaining $P$. pubescens extracts and sample $\mathrm{C} 1$ integrity.

The microcapsules of Pp crude extract or sample $\mathrm{C} 1$ were produced by a spray-drying technique using maltodextrin and arabic gum (1:1) as wall material. The excellence properties of arabic gum as emulsifier, good volatile retention and low viscosity added to low cost of maltodextrin, makes this blend a great choice for wall material in the production of microcapsules. ${ }^{28}$ Images obtained by scanning electron microscopy (images not show) demonstrated that the microencapsulated material has predominantly rough surface, which is very common for this type of technique due to contraction of the particles during the fast drying. ${ }^{29}$

Initially, we evaluated the Pp crude extract stability, employing writhing test for the antinociceptive activity evaluation. This assay was performed with free and microencapsulated Pp extract samples, representative of 0 (T0) and 180 (T180)-day times of the stability study. The results are shown in Figure 6.

The free and microencapsulated extracts demonstrated activity in all the tested dosages $(10,30,100$ and $300 \mathrm{mg} \mathrm{kg}^{-1}$, i.p.). The free and microencapsulated extracts gave $\mathrm{ED}_{50}$ values of $32.3 \mathrm{mg} \mathrm{kg}^{-1}$ and $12.8 \mathrm{mg} \mathrm{kg}^{-1}$ respectively, showing that microencapsulation processes maintained the in vivo extract activity. An assay with the extract's microcapsules was performed after 180 day time, demonstrating that the effect was preserved $\left(\mathrm{ED}_{50} 32 \mathrm{mg} \mathrm{kg}^{-1}\right)$. The free extract was not evaluated in this

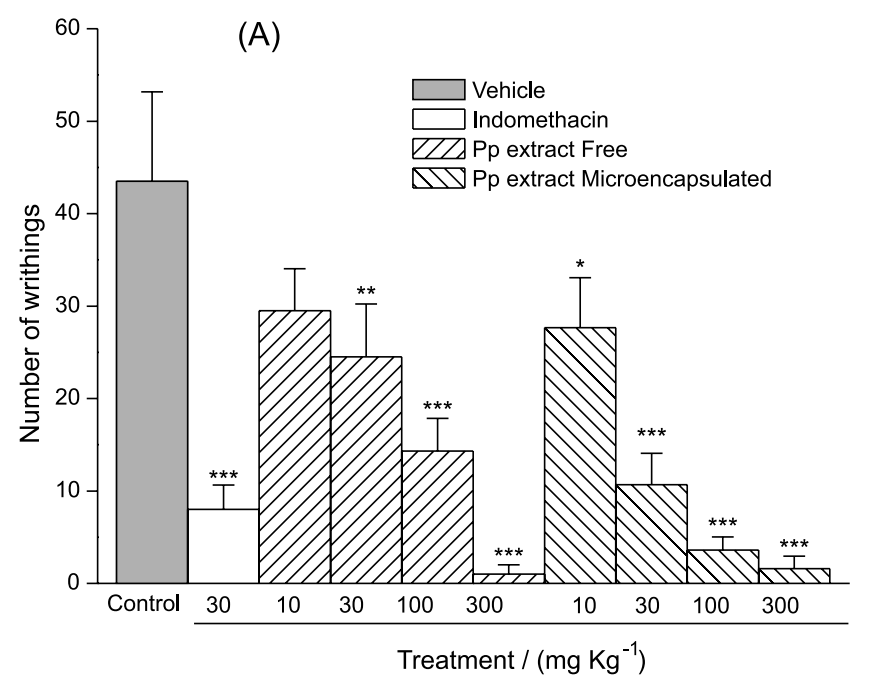

time due to the glassy appearance of the sample, which is not adequate for the antinociceptive assay.

The results showed that spray-drying microencapsulation enabled the use of de Pp extract after stocking, besides preserving the in vivo effect. This technique showed to be a useful alternative to increase shelf life.

To determine the stability of sample $\mathrm{C} 1$, writhing test were performed with free and microencapsulated $\mathrm{C} 1$ at T0, T30, T60, T150 and T180 day-times of stability study. The results of dose-response curves are represented in Figure 7.

The $\mathrm{ED}_{50}$ values, calculated from the results of doseresponse curves, were $10,10.5,13,32$ and $55 \mathrm{mg} \mathrm{kg}^{-1}$ for the free and $10,8,14,39$ and $44 \mathrm{mg} \mathrm{kg}^{-1}$ for the microencapsulated samples (Figure 8).

In the in vivo assays, using the writhing test in mice, both the free and the microencapsulated sample $\mathrm{C} 1$, were effective in the dosages tested, maintaining the original characteristics.

At lower dosages both free and microencapsulated sample $\mathrm{C} 1$, decreased activity as stability study time lapsed (Figure 7), resulting in need of higher dosages necessary to reduce the number of contortions to $50 \%\left(\mathrm{ED}_{50}\right)$ (Figure 8). A gradual decrease in both samples $\mathrm{C} 1$ effectiveness was observed, mainly after 60 days, preserving however their activity until the end of the study (T180-day time).

The free and microencapsulated sample $\mathrm{C} 1$ maintained stability even when stored in drastic temperature and humidity conditions. The microencapsulation process, not only preserves the content, but also solves the inconvenience of low aqueous solubility.

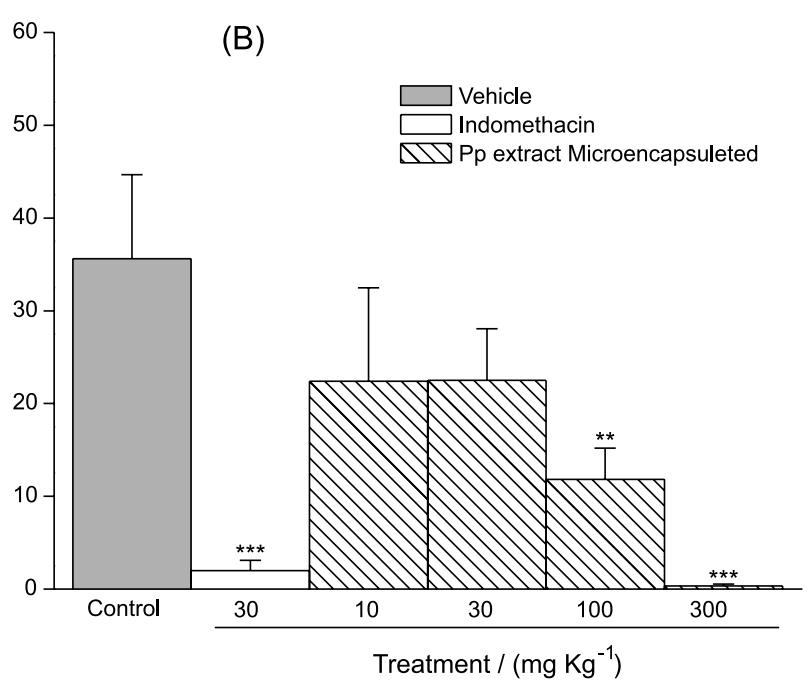

Figure 6. Graph demonstrating effects of free or microencapsulated Pp extract in the acetic acid-induced writhing assay in mice. Animals were pretreated (30 min) with vehicle $\left(10 \mathrm{~mL} \mathrm{~kg}^{-1}\right)$, Pp extracts (doses 10, 30, 100 and $300 \mathrm{mg} \mathrm{kg}^{-1}$; i.p.) or indomethacin $\left(30 \mathrm{mg} \mathrm{kg}^{-1}\right.$; i.p.). The numbers of writhing in the T0 (A) and T180 (B) day-times were measured. Each column represents the mean \pm S.E.M. for six mice in each group. $(* \mathrm{p} \leq 0.05, * * \mathrm{p} \leq 0.01$, $* * * \mathrm{p} \leq 0.001)$. 

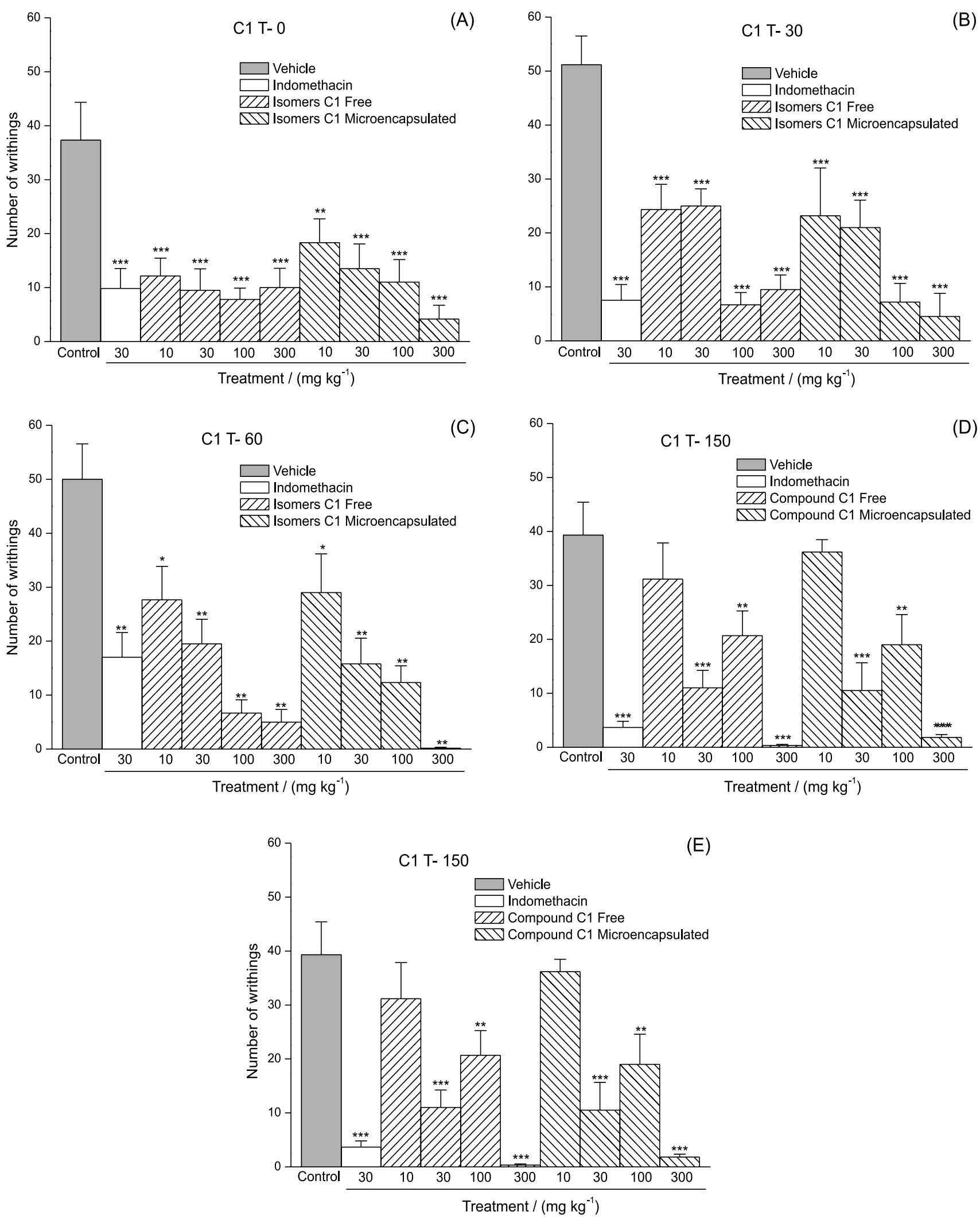

Figure 7. Graph demonstrating effects of free or microencapsulated sample $\mathrm{C} 1$ in the acetic acid-induced writhing assay in mice. Animals were pretreated (30 min) with vehicle $\left(10 \mathrm{~mL} \mathrm{~kg}^{-1}\right), \mathrm{C} 1$ (doses 10,30, 100 and $300 \mathrm{mg} \mathrm{kg}^{-1}$; i.p.) or indomethacin $\left(30 \mathrm{mg} \mathrm{kg}^{-1}\right.$; i.p.). The number of writhing in the times T0 (A), T30 (B), T60 (C), T150 (D) and T180 day-times were measured. Each column represents the mean \pm S.E.M. for six mice in each group. $(* \mathrm{p} \leq 0.05$, $* * \mathrm{p} \leq 0.01$, *** $\mathrm{p} \leq 0.001)$. 


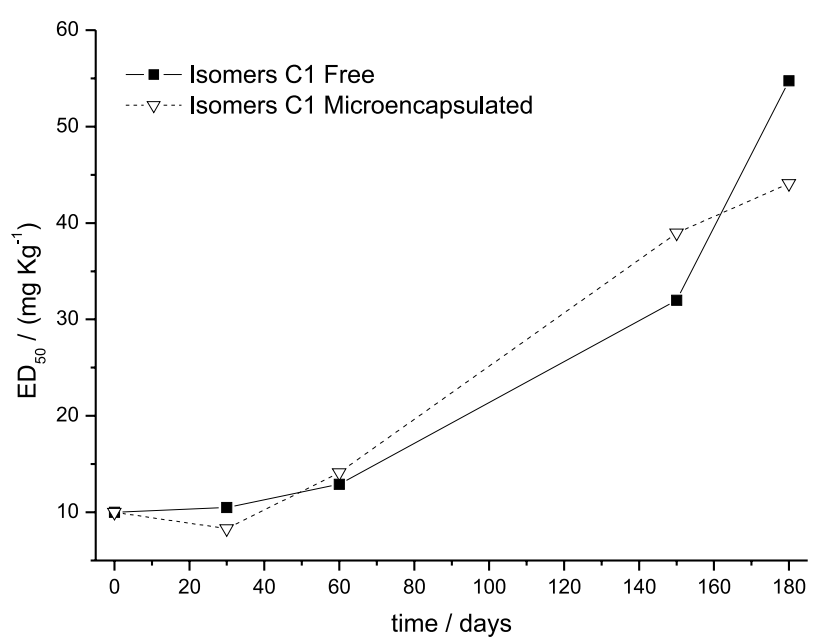

Figure 8. Graph showing the results of the effective dose $\left(\mathrm{ED}_{50}\right)$ of free sample $\mathrm{C} 1$ and microencapsulated at $0,30,60,150$ and 180 days of stability study.

\section{Conclusions}

The most relevant findings of this paper were that sample C1 (i) possess antinociceptive activity revealed by writhing test; (ii) is more effective on the first phase (neurogenic pain) then second one (inflammatory pain) of formalin test; (iii) showed significantly anti-allodynic, but not antihyperalgesic effect; (iv) the microencapsulation kept the activity and integrity of both sample $\mathrm{C} 1$ and $\mathrm{Pp}$ crude extract; $(v)$ microencapsulation by spray drying is a useful alternative to increase shelf life time.

The free and microencapsulated sample $\mathrm{C} 1$ maintained stability even when stored in drastic temperature and humidity conditions. Whereas the crude Pp extract only maintained stability with the microencapsulation process, not only preserving the content, but also solving the inconvenience of low aqueous solubility.

\section{Acknowledgments}

The authors thank CAPES, FAPESP and CNPq for financial support and research fellowships.

\section{References}

1. Pio Correa, M.; Dicionário das Plantas úteis do Brasil e das Exóticas Cultivadas, vol. I, Inst. Bras. Des. Flor.: Rio de Janeiro, 1975.

2. Lorenzi, H.; Árvores Brasileiras. Manual de Identificação e Cultivo de Plantas Arbóreas Nativas do Brasil, vol. 1, $2^{\text {nd }}$ ed., Instituto Plantarum de Estudos da Flora: São Paulo, 1998.

3. Mahjan, J. R.; Monteiro, M. B.; J. Chem. Soc. Perkin Trans. 1973, 1,520 .
4. Fascio, M.; Mors, W. B.; Gilbert, B.; Mahajan, J. R.; Monteiro, M. B.; dos Santos Filho, D.; Vichnewski, W.; Phytochemistry 1975, 15, 201.

5. Campos, A. M.; Silveira, E. R.; Braz-Filho, R.; Teixeira, T. C.; Phytochemistry 1994, 36, 403.

6. Arriaga, A. M.; Gomes, G. A.; Braz-Filho, R.; Fitoterapia 2000 , $71,211$.

7. Spindola, H. M.; Carvalho, J. E.; Ruiz, A. L. T. G.; Rodrigues, R. A. F.; Denny, C.; Sousa, I. M. O.; Tamashiro, J. Y.; Foglio, M. A.; J. Braz. Chem. Soc. 2009, 20, 569.

8. Nunan, E. A.; Carvalho, M. G.; Piloveloso, D.; Braz. J. Med. Biol. Res.1982, 15, 450.

9. Carvalho, J. C. T.; Sertié, J. A. A.; Barbosa, M. V. J.; Patrício, K. C. M.; Caputo, L. R. G.; Sarti, S. J.; Ferreira, L. P.; Bastos, J. K.; J. Ethnopharmacol. 1999, 64, 127.

10. Silva, M. C. C.; Gayer, C. R. M.; Lopes, C. S.; Calixto, N. O.; Reis, P. A.; Passeas, C. P. B.; Paes, M. C.; Dalmau, S. R.; Sabino, K. C. C.; Todeschini, A. R.; Coelho, M. G. P.; J. Pharm. Pharmacol. 2004, 55, 135.

11. Vieira, C. R.; Marques, M. F.; Soares, P. R.; Matuda, L.; De Oliveira, C. M. A. P.; Kato, L.; Da Silva, C. C.; Guillo, L. A.; Phytomedicine 2008, 15, 528.

12. Spindola, H. M.; Servat, L.; Denny, C.; Rodrigues, R. A. F.; Eberlin, M. N.; Cabral, E.; Sousa, I. M. O.; Carvalho, J. E.; Tamashiro, J. Y.; Foglio, M. A.; BMC Pharmacol. 2010, $10,1$.

13. Rosemberg, M.; Young, S. L.; Food Struct.1993, 12, 31.

14. Voipio, H. M.; Baneux, P.; Gomez de Segura, I. A.; Hau, J.; Wolfensohn, S.; Lab. Anim. 2008, 42, 1.

15. Hunskaar, S.; Hole, K.; Pain 1987, 30, 103.

16. Villeti, G.; Bergamarchi, M.; Bassani, F.; Bolzoni, P. T.; Maiorino, M.; Pietra, C.; Rondelli, I.; Chamiot-Clark, P.; Simonato, M.; Barbieri, M.; J. Pharmacol. Exp. Ther. 2003, 306, 804.

17. Randall, R. O.; Selitto, J. J.; Arch. Int. Pharmacodyn. 1957, $111,409$.

18. Collier, H. O.; Dinneen, L. C.; Johnson, C. A.; Schneider. C.; Br. J. Pharmacol. Chemother 1968, 32, 295.

19. Shannon, H. E.; Jones, C. K.; Li, D. L.; Peters, S. C.; Simmons, R. M. A.; Iyengar, S.; Pain 2001, 93, 221.

20. Santos, A. R. S.; Gadotti, V. M.; Oliveira, G. L.; Tibola, D.; Paszuck, A. P.; Neto, A.; Spindola, H. M.; Souza, M. M.; Rodrigues, A. L. S.; Calixto, J. B.; Neuropharmacology 2005, 48, 1021.

21. Santos, A. R. S.; Calixto, J. B.; Neurosci. Lett. 1997, 235, 73.

22. Cunha, M. T.; Verri Jr, W. A.; Silva, J. S.; Poole, S.; Cunha, F. Q.; Ferreira, S. H.; Proc. Natl. Acad. Sci. U. S. A. 2005, 102, 1755.

23. Winter, C. A.; Risley, E. A.; Nuss, G. W.; Proc. Soc. Exp. Biol. Med. 1962, 111, 544.

24. Milano, J.; Rossato, M. F.; Oliveira, S. M.; Drewes, C.; Machado, P.; Beck, P.; Zanatta, N.; Martins, M. A. P.; Mello, 
C. F.; Rubin, M. A.; Ferreira, J.; Bonacorso, H. G.; Life Sci. 2008, 83, 739 .

25. Samad, T.A.; Moore, K. A.; Sapirstein, A.; Billet, S.;Allchorne,A.; Poole, S.; Bonventre, J. V.; Woolf, C. J.; Nature 2001, 410, 471.

26. Cunha, A. M.; Menon, S.; Menon, R.; Couto, A. G.; Burger, C.; Biavatti, M. W.; Phytomedicine 2010, 17, 37.

27. De Souza, K. C. B.; Bassani, V. L.; Schapoval, E. E. S.; Phytomedicine 2007, 14, 102.
28. Fernandes, L. P.; Turatti, I. C. C.; Lopes, N. P.; Ferreira, J. C.; Candido, R. C.; Oliveira, W. P.; Drying Technol. 2008, 26, 1534.

29. Rosemberg, M.; Kopelman, I. J.; Talmon, Y.; J. Agric. Food Chem. 1990, 38, 1288.

Submitted: May 9, 2011

Published online: June 14, 2012

FAPESP has sponsored the publication of this article. 